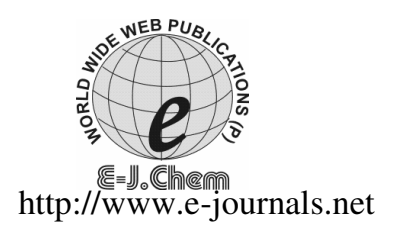

ISSN: 0973-4945; CODEN ECJHAO

E-Journal of Chemistry

2011, 8(4), 1900-1910

\title{
Synthesis and Characterization of Lanthanide(III) Nitrate Complexes with Terdentate ONO Donor Hydrazone Derived from 2-Benzimidazolyl Mercaptoaceto Hydrazide and $o$-Hydroxy Aromatic Aldehyde
}

\author{
VINAYAK M. NAIK and NIRMALKUMAR B. MALLUR ${ }^{\S *}$ \\ Department of Chemistry, Government Arts and Science College \\ Karwar-581 301, Karnataka, India \\ ${ }^{\S} \mathrm{P}$ G Department of Studies in Chemistry \\ Karnatak University, Dharwad-580 003, India \\ nirmalmallur@rediffmail.com
}

Received 6 October 2010; Accepted 16 December 2010

\begin{abstract}
A few eight coordinated complexes of lanthanide(III) nitrate with 2-benzimidazolyl mercaptoaceto hydrazone ligand $\left(\mathrm{LH}_{2}\right)$ with the general formula $\left[\mathrm{Ln}(\mathrm{LH})_{2} \mathrm{NO}_{3}\right] \mathrm{H}_{2} \mathrm{O}$ (where $\mathrm{Ln}=\mathrm{La}, \mathrm{Pr}, \mathrm{Nd}, \mathrm{Sm}$ and $\mathrm{Gd}$ ) have been synthesized and characterized by elemental analysis, magnetic susceptibility, molar conductance, UV-Visible, IR and ${ }^{1} \mathrm{H}$ NMR spectral studies. The experimental data sustain stoichiometry of 1:2 (metal/ligand) for the complexes. The spectral data shows that the ligand reacts in keto form and behaves as monobasic terdentate in nature. The nitrate appears to coordinate in the bidentate fashion to the metal ion. The thermal stabilities of the complexes have been studied by TGA and their kinetic parameters were calculated using Coats-Redfern and MKN methods. The antimicrobial activity studies have been under taken and results are discussed.
\end{abstract}

Keywords: Hydrazone, Lanthanide(III) nitrate complexes, Spectral data, Kinetic parameters, Antimicrobial activity

\section{Introduction}

The structural chemistry of the lanthanides is fascinating because they have a tendency to form complexes with coordination number greater than six up to twelve. Due to the large size of the ions and their tendency to form ionic bonds rather than covalent bonds lead to complexes with higher coordination numbers. Not only monodentate or simple bidentate but 
also polydentate ligands with small bytes often yield complexes with higher coordination numbers ${ }^{1}$. The structural versatility arises from the lack of strong crystal efforts for the $4 \mathrm{f}$ electronic configurations as well as from the large ionic radii of these metal ions, which change markedly with oxidation number or atomic number of the lanthanides. In recent years, the chemistry of hydrazones has been intensively investigated, owing to their coordinative capability, their pharmacological activity ${ }^{2}$ and their use in analytical chemistry as metal extracting agents. The study of the complexes formed with hydrazones is very interesting because of the tautomerism exhibited by these ligands. The chromophore group $-\mathrm{CO}-\mathrm{NH}-\mathrm{N}<$ of the ligand can enters the inner sphere of the complex either in the keto or enol form. This tendency depends upon the $\mathrm{pH}$ of the medium employed in the synthesis of the complex, the nature of the substituents attached to the carbonyl carbon atom, $\beta$ - nitrogen atom, the anion of the metal salt and the metal ion. The tautomeric nature of the hydrazone and its versatility in showing higher coordination number of lanthanide ions attracted our attention to carry out the studies on lanthanide complexes. In the continuation of earlier studies on the complexes with the ligands of 2-benzimidazolyl mercaptoaceto hydrazide and $o$-hydroxy aromatic aldehydes ${ }^{3-5}$, we report here the synthesis and structural studies of few lanthanide(III) nitrate complexes with 2-benzimidazolyl mercaptoaceto hydrazones.

\section{Experimental}

All reagents and solvents were used are of the type AR grade and were used without further purification. 2-benzimidazolyl mercaptoaceto hydrazide was prepared according to reported standard method ${ }^{3,6}$. Lanthanum nitrate pentahydrate $\mathrm{La}\left(\mathrm{NO}_{3}\right)_{3} \cdot 5 \mathrm{H}_{2} \mathrm{O}(99 \%)$ was obtained from BDH chemicals Ltd. Other lanthanides were procured from Indian Rare Earths Ltd., as oxides (99.9\% pure). The corresponding metal nitrates were prepared by dissolving a slight excess of respective lanthanide oxide in hot $50 \%(\mathrm{v} / \mathrm{v})$ nitric acid $(25 \mathrm{~mL})$. The undissolved oxide was removed by filtration in each case and the filtrate was concentrated on a water bath to $\sim 25 \%$ of the original volume. The resulting concentrate was cooled to obtain the crystals of lanthanide nitrate. The lanthanide nitrates so prepared were used for the preparation of complexes. The metal content in complexes was determined by complexometric EDTA titration using xylenolorange as indicator at $\mathrm{pH}$. The nitrate present in the complexes is determined using a nitron reagent. The elemental analyses of complexes were recorded on Elemental analyzer Heraeus Carlo Erba-1108. The electronic spectra of lanthanide(III) nitrate complexes were recorded in DMF on Hitachi 150-20 spectrophotometer in the region 200-900 $\mathrm{nm}$, infrared spectra were recorded in $\mathrm{KBr}$ matrix using Impact-410 Nicolet FTIR spectrometer in the range 4000-400 $\mathrm{cm}^{-1}$ and ${ }^{1} \mathrm{H}$ NMR spectra were recorded in DMSO solvent on Bruker Avance-300 spectrometer using TMS as an internal standard. Molar conductances of the complexes were measured on Elico CM-82 conductivity bridge in DMF solution at concentration $\sim 10^{-3} \mathrm{M}$. The magnetic susceptibilities were measured at room temperature on Guoy balance using $\mathrm{Hg}\left[\mathrm{Co}(\mathrm{SCN})_{4}\right]$ as calibrant. TG and DTG were carried out from room temperature to $\sim 800{ }^{\circ} \mathrm{C}$ in dynamic air atmosphere on a Rigaku TAS-100 model thermal analyzer maintaining a heating rate of $10{ }^{\circ} \mathrm{C} / \mathrm{min}$. Kinetic parameters were computed from the thermal decomposition data. The metal complexes together with the hydrazone ligands were tested to emphasize their activities against the two bacteria Escherichia coli and Bacillus cirroflagellasus and two fungal species Aspergillus niger and Candida albicans. 


\section{Preparation of 2-benzimidazolyl mercaptoaceto hydrazone ligand $\left(\mathrm{LH}_{2}\right)$}

A mixture of an ethanolic solution of $0.001 \mathrm{~mol}$ of 2-benzimidazolyl mercaptoaceto hydrazide and $0.001 \mathrm{~mol}$ of $o$-hydroxy aromatic aldehyde in ethanol was refluxed on a steam bath for $\sim 3 \mathrm{~h}$. The mixture was concentrated, cooled and the separated precipitate was filtered, washed with water and recrystallised from alcohol. The purity of the ligand $\left(\mathrm{LH}_{2}\right)$ (Figure.1) was checked by TLC.

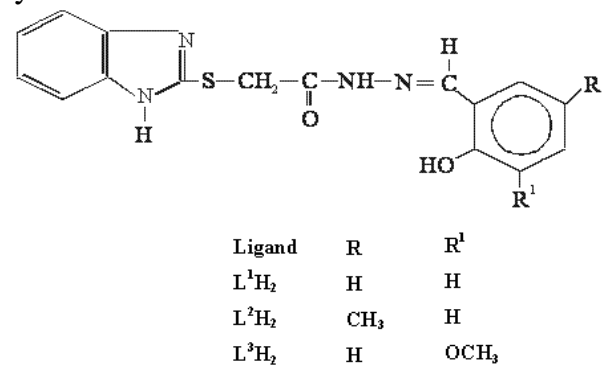

Figure 1. Structure of the ligand $\left(\mathrm{LH}_{2}\right)$

\section{Preparation of lanthanide(III) nitrate complexes}

An alcoholic solution of lanthanide(III) nitrate $(0.01 \mathrm{~mol} / 20 \mathrm{~mL})$ was added to 2-benzimidazolyl mercaptoaceto hydrazone $(0.02 \mathrm{~mol} / 20 \mathrm{~mL}$ ethanol $)$ with constant stirring. The mixture was refluxed on a water bath for $\sim 4 \mathrm{~h}$ and then $\mathrm{pH}$ of the mixture was raised to 6.5 by adding dropwise alcoholic ammonia. The coloured complex thus formed was filtered, washed with alcohol and then dried in vacuum over anhydrous $\mathrm{CaCl}_{2}$ in a desiccator (yield 68-76\%).

\section{Results and Discussion}

The prepared lanthanide(III) nitrate complexes are coloured, non-hygroscopic and insoluble in organic non-polar solvents like benzene, carbon tetrachloride etc., but soluble in organic polar solvents like DMF and DMSO. From elemental analyses data (Table 1) reveal that the lanthanide(III) nitrate complexes have a metal/ligand ratio of 1:2. The observed molar conductance (Table 1) values measured in DMF solution fall in the range $\left(18-27 \mathrm{omh}^{-1} \mathrm{~cm}^{2}\right.$ $\mathrm{mol}^{-1}$ ), these observed values of the molar conductance are well within the expected range for non-electrolytes ${ }^{7}$. Therefore, the molar conductivity data suggest that the nitrate ion present within coordination sphere in the complexes.

\section{Magnetic susceptibility}

Lanthanum(III) nitrate complexes are diamagnetic as may be expected from their closed shell electronic configuration and absence of unpaired electron. The magnetic moments obtained at room temperature for other tripositive lanthanide(III) nitrate complexes show that paramagnetic nature. The magnetic moments observed are compared with the theoretical spin orbital coupling values (the Hund's values) and the values calculated form Van Vleek formula of the respective lanthanide ion. These values agree with each other for the lanthanide(III) nitrate complexes except samarium(III) nitrate complexes. This indicate the non-involvement of 4 f-orbitals in bond formation. In samarium(III) nitrate complex a little deviation from Van Vleek values indicates little participation of $4 \mathrm{f}$-electrons in bond formation. In the samarium(III) nitrate complexes, a slight higher values observed may presumably be due to temperature dependent magnetism ${ }^{8}$ on account of low $J$-separation. 
Table 1. Analytical, molar conductance and magnetic susceptibility data of lanthanide(III) nitrate complexes

\begin{tabular}{|c|c|c|c|c|c|c|c|}
\hline \multirow{2}{*}{ Ligand/Complex } & \multicolumn{5}{|c|}{ Found (Calculated) $\%$} & \multirow{2}{*}{$\begin{array}{c}\text { Molar } \\
\text { conductance, } \\
\mathrm{ohm}^{-1} \mathrm{~cm}^{2} \mathrm{~mol}^{-1}\end{array}$} & \multirow{2}{*}{$\begin{array}{c}\mu_{\text {eff }} \\
\text { (B.M. }\end{array}$} \\
\hline & $\mathrm{C}$ & $\mathrm{H}$ & $\mathrm{N}$ & Metal & Nitrate & & \\
\hline $\mathrm{C}_{16} \mathrm{H}_{14} \mathrm{~N}_{4} \mathrm{O}_{2} \mathrm{~S}\left(\mathrm{~L}^{1} \mathrm{H}_{2}\right)$ & $\begin{array}{c}57.78 \\
(58.89)\end{array}$ & $\begin{array}{c}4.32 \\
(4.29)\end{array}$ & $\begin{array}{c}17.14 \\
(17.18)\end{array}$ & - & - & 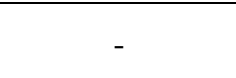 & \\
\hline$\left[\mathrm{La}\left(\mathrm{L}^{1} \mathrm{H}\right)_{2} \mathrm{NO}_{3}\right] \mathrm{H}_{2} \mathrm{O}$ & $\begin{array}{l}44.72 \\
(44.29)\end{array}$ & $\begin{array}{c}3.03 \\
(3.02)\end{array}$ & $\begin{array}{c}14.61 \\
(14.52)\end{array}$ & $\begin{array}{c}16.17 \\
(16.01)\end{array}$ & $\begin{array}{l}7.18 \\
(7.14)\end{array}$ & 24.33 & diam \\
\hline$\left[\operatorname{Pr}\left(\mathrm{L}^{1} \mathrm{H}\right)_{2} \mathrm{NO}_{3}\right] \mathrm{H}_{2} \mathrm{O}$ & $\begin{array}{c}44.08 \\
(44.19)\end{array}$ & $\begin{array}{c}2.98 \\
(3.01)\end{array}$ & $\begin{array}{c}14.47 \\
(14.49)\end{array}$ & $\begin{array}{c}16.23 \\
(16.20)\end{array}$ & $\begin{array}{l}7.10 \\
(7.13)\end{array}$ & 20.27 & 3.42 \\
\hline$\left[\mathrm{Nd}\left(\mathrm{L}^{1} \mathrm{H}\right)_{2} \mathrm{NO}_{3}\right] \mathrm{H}_{2} \mathrm{O}$ & $\begin{array}{c}44.27 \\
(44.02)\end{array}$ & $\begin{array}{c}3.03 \\
(3.01)\end{array}$ & $\begin{array}{l}14.57 \\
(14.43)\end{array}$ & $\begin{array}{l}16.61 \\
(16.52)\end{array}$ & $\begin{array}{l}7.03 \\
(7.10)\end{array}$ & 24.74 & 3.45 \\
\hline$\left[\mathrm{Sm}\left(\mathrm{L}^{1} \mathrm{H}\right)_{2} \mathrm{NO}_{3}\right] \mathrm{H}_{2} \mathrm{O}$ & $\begin{array}{c}43.86 \\
(43.71)\end{array}$ & $\begin{array}{c}2.92 \\
(2.98)\end{array}$ & $\begin{array}{l}14.45 \\
(14.33)\end{array}$ & $\begin{array}{c}17.14 \\
(17.10)\end{array}$ & $\begin{array}{c}7.02 \\
(7.05)\end{array}$ & 22.14 & 1.21 \\
\hline$\left[\mathrm{Gd}\left(\mathrm{L}^{1} \mathrm{H}\right)_{2} \mathrm{NO}_{3}\right] \mathrm{H}_{2} \mathrm{O}$ & $\begin{array}{c}43.17 \\
(43.38)\end{array}$ & $\begin{array}{c}2.91 \\
(2.95)\end{array}$ & $\begin{array}{c}14.37 \\
(14.22)\end{array}$ & $\begin{array}{c}17.64 \\
(17.74)\end{array}$ & $\begin{array}{c}7.06 \\
(6.98)\end{array}$ & 16.71 & 7.76 \\
\hline $\mathrm{C}_{17} \mathrm{H}_{16} \mathrm{~N}_{4} \mathrm{O}_{2} \mathrm{~S}\left(\mathrm{~L}^{2} \mathrm{H}_{2}\right)$ & $\begin{array}{c}59.12 \\
(60.01)\end{array}$ & $\begin{array}{c}4.63 \\
(4.70)\end{array}$ & $\begin{array}{l}16.26 \\
(16.47)\end{array}$ & - & - & - & - \\
\hline$\left[\mathrm{La}\left(\mathrm{L}^{2} \mathrm{H}\right)_{2} \mathrm{NO}_{3}\right] \mathrm{H}_{2} \mathrm{O}$ & $\begin{array}{c}45.26 \\
(45.59)\end{array}$ & $\begin{array}{c}3.34 \\
(3.37)\end{array}$ & $\begin{array}{c}14.02 \\
(14.07)\end{array}$ & $\begin{array}{c}15.69 \\
(15.50)\end{array}$ & $\begin{array}{c}6.88 \\
(6.92)\end{array}$ & 17.94 & diam \\
\hline$\left[\operatorname{Pr}\left(\mathrm{L}^{2} \mathrm{H}\right)_{2} \mathrm{NO}_{3}\right] \mathrm{H}_{2} \mathrm{O}$ & $\begin{array}{c}45.61 \\
(45.48)\end{array}$ & $\begin{array}{c}3.33 \\
(3.36)\end{array}$ & $\begin{array}{l}14.07 \\
(14.04)\end{array}$ & $\begin{array}{l}15.78 \\
(15.69)\end{array}$ & $\begin{array}{c}6.87 \\
(6.91)\end{array}$ & 21.96 & 3.46 \\
\hline$\left[\mathrm{Nd}\left(\mathrm{L}^{2} \mathrm{H}\right)_{2} \mathrm{NO}_{3}\right] \mathrm{H}_{2} \mathrm{O}$ & $\begin{array}{c}44.96 \\
(45.22)\end{array}$ & $\begin{array}{c}3.52 \\
(3.54)\end{array}$ & $\begin{array}{c}13.89 \\
(13.96)\end{array}$ & $\begin{array}{l}15.95 \\
(15.98)\end{array}$ & $\begin{array}{c}6.83 \\
(6.87)\end{array}$ & 19.08 & 3.48 \\
\hline$\left[\mathrm{Sm}\left(\mathrm{L}^{2} \mathrm{H}\right)_{2} \mathrm{NO}_{3}\right] \mathrm{H}_{2} \mathrm{O}$ & $\begin{array}{c}44.67 \\
(44.91)\end{array}$ & $\begin{array}{c}3.46 \\
(3.52)\end{array}$ & $\begin{array}{c}13.81 \\
(13.87)\end{array}$ & $\begin{array}{c}16.38 \\
(16.55)\end{array}$ & $\begin{array}{c}6.72 \\
(6.81)\end{array}$ & 18.16 & 1.23 \\
\hline$\left[\mathrm{Gd}\left(\mathrm{L}^{2} \mathrm{H}\right)_{2} \mathrm{NO}_{3}\right] \mathrm{H}_{2} \mathrm{O}$ & $\begin{array}{c}45.01 \\
(44.67)\end{array}$ & $\begin{array}{c}3.37 \\
(3.30)\end{array}$ & $\begin{array}{c}13.62 \\
(13.79)\end{array}$ & $\begin{array}{c}16.98 \\
(17.20)\end{array}$ & $\begin{array}{c}6.67 \\
(6.78)\end{array}$ & 21.44 & 7.69 \\
\hline $\mathrm{C}_{17} \mathrm{H}_{16} \mathrm{~N}_{4} \mathrm{O}_{3} \mathrm{~S}\left(\mathrm{~L}^{3} \mathrm{H}_{2}\right)$ & $\begin{array}{c}56.01 \\
(57.30)\end{array}$ & $\begin{array}{c}4.51 \\
(4.49)\end{array}$ & $\begin{array}{c}15.76 \\
(15.73)\end{array}$ & - & - & - & - \\
\hline$\left[\mathrm{La}\left(\mathrm{L}^{3} \mathrm{H}\right)_{2} \mathrm{NO}_{3}\right] \mathrm{H}_{2} \mathrm{O}$ & $\begin{array}{c}43.55 \\
(43.92)\end{array}$ & $\begin{array}{c}3.42 \\
(3.44)\end{array}$ & $\begin{array}{l}13.48 \\
(13.56)\end{array}$ & $\begin{array}{c}14.79 \\
(14.95)\end{array}$ & $\begin{array}{c}6.52 \\
(6.67)\end{array}$ & 22.16 & diam \\
\hline$\left[\operatorname{Pr}\left(\mathrm{L}^{3} \mathrm{H}\right)_{2} \mathrm{NO}_{3}\right] \mathrm{H}_{2} \mathrm{O}$ & $\begin{array}{c}44.03 \\
(43.82)\end{array}$ & $\begin{array}{c}3.22 \\
(3.24)\end{array}$ & $\begin{array}{c}13.44 \\
(13.52)\end{array}$ & $\begin{array}{c}15.25 \\
(15.12)\end{array}$ & $\begin{array}{c}6.68 \\
(6.65)\end{array}$ & 18.44 & 3.41 \\
\hline$\left[\mathrm{Nd}\left(\mathrm{L}^{3} \mathrm{H}\right)_{2} \mathrm{NO}_{3}\right] \mathrm{H}_{2} \mathrm{O}$ & $\begin{array}{c}43.41 \\
(43.67)\end{array}$ & $\begin{array}{c}3.27 \\
(3.27)\end{array}$ & $\begin{array}{c}13.52 \\
(13.48)\end{array}$ & $\begin{array}{c}15.57 \\
(15.42)\end{array}$ & $\begin{array}{c}6.68 \\
(6.63)\end{array}$ & 21.11 & 3.42 \\
\hline$\left[\mathrm{Sm}\left(\mathrm{L}^{3} \mathrm{H}\right)_{2} \mathrm{NO}_{3}\right] \mathrm{H}_{2} \mathrm{O}$ & $\begin{array}{c}43.49 \\
(43.38)\end{array}$ & $\begin{array}{c}3.24 \\
(3.21)\end{array}$ & $\begin{array}{c}13.36 \\
(13.39)\end{array}$ & $\begin{array}{c}16.23 \\
(15.97)\end{array}$ & $\begin{array}{c}6.64 \\
(6.58)\end{array}$ & 18.32 & 1.20 \\
\hline$\left[\mathrm{Gd}\left(\mathrm{L}^{3} \mathrm{H}\right)_{2} \mathrm{NO}_{3}\right] \mathrm{H}_{2} \mathrm{O}$ & $\begin{array}{c}42.94 \\
(43.07) \\
\end{array}$ & $\begin{array}{c}3.33 \\
(3.37)\end{array}$ & $\begin{array}{c}13.24 \\
(13.31)\end{array}$ & $\begin{array}{c}16.47 \\
(16.60)\end{array}$ & $\begin{array}{c}6.52 \\
(6.54)\end{array}$ & 20.92 & 7.73 \\
\hline
\end{tabular}

\section{Electronic spectra}

The electronic spectra of ligands show bands at 30550-26985, 33248-30010 and $34630-32980 \mathrm{~cm}^{-1}$ whereas in lanthanide(III) nitrate complexes these bands are shifted to higher or lower frequency sides. This shift may be due to ligand to metal charge transfer transitions ${ }^{9,10}$. No absorption band due to $\mathrm{f}-\mathrm{f}$ transition of lanthanide(III) ions could be located in the visible region in the spectra of the complexes. This is probably due to the fact that the $\mathrm{f}-\mathrm{f}$ bands are weak and are obscured by the intense charge transfer bands ${ }^{10,11}$. 


\section{Infrared spectra}

The IR spectra analysis gave information about the mode of coordination of the ligand $\left(\mathrm{LH}_{2}\right)$ to the lanthanide(III) ions. The characteristic bands are presented in Table 2. The IR spectra of ligands show strong sharp bands in the regions 3230-3214, 3018-3010 and 1524-1502 cm are assigned to the vibrations of $v(\mathrm{~N}-\mathrm{H})$ of hydrazide, $v(\mathrm{~N}-\mathrm{H})$ of imidazole moiety and phenolic $v(\mathrm{C}-\mathrm{O})$ respectively ${ }^{5}$. The broad band around $3445-3420 \mathrm{~cm}^{-1}$ in the IR spectra of ligands assigned to $v(\mathrm{OH})$, which were found to have disappeared in all their respective complexes, thereby indicating the involvement of phenolic oxygen in bondy with metal ions through deprotonation and the positive shifting of phenolic $v(\mathrm{C}-\mathrm{O})$ in all the complexes confirms the involvement of phenolic $\mathrm{OH}$ in the complex formation. In the ligands a strong sharp band observed in the region in the region $1705-1685 \mathrm{~cm}^{-1}$ is assigned to $v(C=O)$, which was shifted to $23-41 \mathrm{~cm}^{-1}$ in all complexes indicates the involvement of the carbonyl group in complexation with the metal ion and another strong sharp band observed in region $1652-1648 \mathrm{~cm}^{-1}$ is assigned to azomethine $v(C=N)$ group, lowering of $v(C=N) 26-32 \mathrm{~cm}^{-1}$ in the complexes as compared to its ligand is due to the reduction of double bond character carbonnitrogen bond of the azomethine group ${ }^{11,12}$. The band due to $v(\mathrm{NH})$ remains unaltered in its position and intensity, it clearly suggests the reaction of ligand in kero from. The broad absorption band in the region $3490-3340 \mathrm{~cm}^{-1}$ indicates the presence of water molecule in the complexes and further confirmed by thermogravimetric studies. The present lanthanide(III) nitrate complexes show six absorption bands in the regions 1501-1469, 1302-1268, 1037-1017, $870-855,765-750$ and 703-687 $\mathrm{cm}^{-1}$ assigned to respectively to $v_{4}, v_{1}, v_{2}, v_{6}, v_{3}$ and $v_{5}$ vibrations of the coordinated $C_{2 v}$ nitrate group. The magnitude of $v_{4}-v_{1}$ and $v_{3}-v_{5}$ are in the range of 205$195 \mathrm{~cm}^{-1}$ and $66-60 \mathrm{~cm}^{-1}$ respectively indicates the nitrate group is in bidentate fashion ${ }^{13}$.

Table 2. Significant IR frequencies $\left(\mathrm{cm}^{-1}\right)$ of the ligands and their lanthanide(III) nitrate complexes

\begin{tabular}{|c|c|c|c|c|c|c|c|c|c|c|c|c|c|}
\hline \multirow{2}{*}{ Ligand/Complex } & \multirow{2}{*}{ 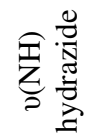 } & \multirow{2}{*}{ 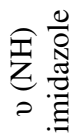 } & \multirow{2}{*}{$\underbrace{0}_{0}$} & \multirow{2}{*}{$\underbrace{\overbrace{0}^{\pi}}_{0}$} & \multirow{2}{*}{ 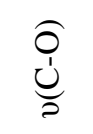 } & \multirow{2}{*}{ 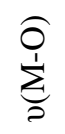 } & \multirow{2}{*}{$\sum_{0}^{Z_{1}^{1}}$} & \multicolumn{6}{|c|}{$\mathrm{NO}_{3}{ }^{-}$frequencies } \\
\hline & & & & & & & & $v_{4}$ & $\mathrm{v}_{1}$ & $v_{2}$ & $v_{6}$ & $v_{3}$ & $v_{5}$ \\
\hline $\mathrm{C}_{16} \mathrm{H}_{14} \mathrm{~N}_{4} \mathrm{O}_{2} \mathrm{~S}\left(\mathrm{~L}^{1} \mathrm{H}_{2}\right)$ & 3230 & 3010 & 1705 & 1650 & 1524 & - & - & - & 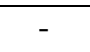 & & - & - & - \\
\hline$\left.)_{2} \mathrm{NO}_{3}\right] \mathrm{H}_{2} \mathrm{O}$ & 3228 & 3008 & 1676 & 1622 & 1546 & 492 & 428 & 1497 & 1294 & 1026 & 863 & 759 & 698 \\
\hline$\left[\operatorname{Pr}\left(\mathrm{L}^{1} \mathrm{H}\right)_{2} \mathrm{NO}_{3}\right] \mathrm{H}_{2} \mathrm{O}$ & 3230 & 3010 & 1664 & 1620 & 1542 & 497 & 434 & & & & 849 & 756 & 695 \\
\hline$\left[\mathrm{Nd}\left(\mathrm{L}^{1} \mathrm{H}\right)_{2} \mathrm{NO}_{3}\right] \mathrm{H}_{2} \mathrm{O}$ & 3228 & 3014 & 1680 & 1618 & 1552 & 499 & 437 & & 1295 & 28 & 863 & 758 & 695 \\
\hline$\left[\mathrm{Sm}\left(\mathrm{L}^{1} \mathrm{H}\right)_{2} \mathrm{NO}_{3}\right] \mathrm{H}_{2} \mathrm{O}$ & 3231 & 3012 & 1678 & 1622 & 1547 & 504 & 439 & & 292 & 1 & 869 & 765 & 701 \\
\hline$\left[\mathrm{Gd}\left(\mathrm{L}^{1} \mathrm{H}\right)_{2} \mathrm{NO}_{3}\right] \mathrm{H}_{2} \mathrm{O}$ & 3232 & 3010 & 1674 & 1618 & 1541 & 497 & 431 & & 1299 & 1029 & 861 & 763 & 698 \\
\hline$\left(\mathrm{L}^{2} \mathrm{H}_{2}\right)$ & 3222 & 3018 & 1685 & 1648 & 1502 & - & - & - & - & - & - & - & - \\
\hline $\mathrm{H}_{2} \mathrm{O}$ & 3210 & 3020 & 1662 & 1616 & 1540 & 488 & 419 & 1486 & 1287 & 1017 & 856 & 750 & 68 \\
\hline $\left.\mathrm{O}_{3}\right] \mathrm{H}_{2} \mathrm{O}$ & 3219 & 3016 & 1658 & 1618 & 1546 & 484 & 426 & & 282 & 023 & 860 & & 690 \\
\hline $\left.\mathrm{O}_{3}\right] \mathrm{H}_{2} \mathrm{O}$ & 3218 & 3020 & 1662 & 1622 & 1549 & 486 & 426 & & 1301 & 1034 & 858 & 756 & 690 \\
\hline$\left[\mathrm{Sm}\left(\mathrm{L}^{2} \mathrm{H}\right)_{2} \mathrm{NO}_{3}\right] \mathrm{H}_{2} \mathrm{O}$ & 3220 & 3018 & 1653 & 11621 & 1539 & 499 & 436 & 1498 & 1302 & 1033 & 860 & 759 & 699 \\
\hline$\left[\mathrm{Gd}\left(\mathrm{L}^{2} \mathrm{H}\right)_{2} \mathrm{NO}_{3}\right] \mathrm{H}_{2} \mathrm{O}$ & 3218 & 3016 & 1662 & 1622 & 1536 & 499 & 439 & 1488 & 1296 & 1037 & 859 & 765 & 702 \\
\hline $\mathrm{C}_{17} \mathrm{H}_{16} \mathrm{~N}_{4} \mathrm{O}_{3} \mathrm{~S}\left(\mathrm{~L}^{3} \mathrm{H}_{2}\right)$ & 3214 & 3014 & 1696 & 1652 & 1513 & - & - & - & - & - & - & - & - \\
\hline $3 \mathrm{H}_{2} \mathrm{O}$ & 3216 & 3012 & 1670 & 1626 & 1538 & 502 & 431 & 1469 & 1268 & 1030 & 861 & 753 & 69 \\
\hline $\left.\mathrm{NO}_{3}\right] \mathrm{H}_{2} \mathrm{O}$ & 3215 & 3013 & 1672 & 1624 & 1539 & 492 & 434 & 1493 & 1297 & 103 & 69 & 76 & 703 \\
\hline $\left.\mathrm{H})_{2} \mathrm{NO}_{3}\right] \mathrm{H}_{2} \mathrm{O}$ & 3214 & 3010 & 1666 & 1612 & 1542 & 501 & 440 & 1488 & 1290 & 1030 & 855 & 761 & 698 \\
\hline$\left[\mathrm{Sm}\left(\mathrm{L}^{3} \mathrm{H}\right)_{2} \mathrm{NO}_{3}\right] \mathrm{H}_{2} \mathrm{O}$ & 3215 & 3016 & 1668 & 1622 & 1540 & 488 & 427 & 1487 & 1288 & 1027 & 863 & 759 & 697 \\
\hline$\left[\mathrm{Gd}\left(\mathrm{L}^{3} \mathrm{H}\right)_{2} \mathrm{NO}_{3}\right] \mathrm{H}_{2} \mathrm{O}$ & 3216 & 3012 & 1672 & 1620 & 1529 & 482 & 422 & 1488 & 1292 & 1033 & 865 & 758 & 696 \\
\hline
\end{tabular}


Apart from these, two other non-ligand bands are also observed, one weak band observed in the range of 504-482 $\mathrm{cm}^{-1}$ which may be attributed to $v(\mathrm{M}-\mathrm{O})$ and the other weak around $440-419 \mathrm{~cm}^{-1}$ which may be assigned to $v(\mathrm{M}-\mathrm{N})$ vibrations. The band $v(\mathrm{M}-\mathrm{O})$ usually occurs at higher frequency than $v(\mathrm{M}-\mathrm{N})$ and $v(\mathrm{M}-\mathrm{O})$ band usually broad and stronger than the $v(\mathrm{M}-\mathrm{N})$ band. This may be due to large dipole moment change in the vibration of $\mathrm{M}-\mathrm{O}$ band in comparison to that in the $\mathrm{M}-\mathrm{N}$ band ${ }^{11,12}$.

\section{${ }^{1}$ H NMR spectra}

The spectrum of ${ }^{1} \mathrm{H}$ NMR in DMSO- $\mathrm{d}_{6}$ solvent used. In the ligand, the eight aromatic protons have resonated in region $\delta 7.26-7.93 \mathrm{ppm}(\mathrm{m}, 8 \mathrm{H}, \mathrm{Ar}-\mathrm{H})$ as multiplet, in $\mathrm{La}(\mathrm{III})$ nitrate complex these protons have been observed in the region $\delta 7.18-7.79 \mathrm{ppm}(\mathrm{m}, 8 \mathrm{H}, \mathrm{Ar}-\mathrm{H})$ as multiplet. The peaks appear at $\delta 12.08 \mathrm{ppm}(\mathrm{s}, 1 \mathrm{H}$, phenolic-OH), $\delta 11.05 \mathrm{ppm}(\mathrm{s}, 1 \mathrm{H},-\mathrm{NH}$ of hydrazine), $\delta 12.72 \mathrm{ppm}\left(\mathrm{s}, 1 \mathrm{H},-\mathrm{NH}\right.$ of imidazole moiety), $\delta 3.64 \mathrm{ppm}\left(\mathrm{s}, 2 \mathrm{H},-\mathrm{CH}_{2}\right)$ and $\delta 8.82 \mathrm{ppm}(\mathrm{s}, 1 \mathrm{H}$, $-\mathrm{CH}=\mathrm{N}$ ) as singlets in the ligand, but in the case of $\mathrm{La}(\mathrm{III})$ nitrate complex the peak of phenolic $-\mathrm{OH}$ has been disappeared indicating the involvement of phenolic oxygen in the coordination via deprotonation. The peaks of both the $-\mathrm{NH}$ group are unaffected in the spectrum of the complex. The $-\mathrm{CH}_{2}$ peak is appeared at $\delta 4.25 \mathrm{ppm}$ in the complex, this downfield shift suggest its deshielding because of the coordination of carbonyl group and the peak of the azomethine proton is situated through a lower field with $\delta=0.22 \mathrm{ppm}$, this deshielding results the coordination through the nitrogen of the azomethine group to the metal ion. The ${ }^{1} \mathrm{H}$ NMR data gave information that the ligand is in keto form and it coordinated to the metal atom through the carbonyl oxygen, azomethine nitrogen and phenolic oxygen via deprotonation.

\section{Thermal analysis}

The thermal behaviour including the stability ranges, peak temperatures, percentage of weight loss and percentage of residue obtained after decomposition process of the representative complexes have been reported in Table 3. The thermoanalytical studies of the complexes reveal that, the decomposition proceeds into three stages. The complexes undergo the first stage of decomposition in the range $328-408 \mathrm{~K}$, the weight loss corresponds to the loss of one uncoordinated water molecule in the lattice while the second stage decomposition occurs in the range $378-718 \mathrm{~K}$, the weight loss indicates the loss of one nitrate and one ligand molecule. The third stage decomposition occurs in the range 678-998 K, indicating the loss of another ligand molecule. A plateau is obtained, which indicates the formation of stable metal oxides $\left(\operatorname{Ln}_{2} \mathrm{O}_{3}\right)$. The weight of the residue obtained agrees well with the calculated value. The kinetic parameters (Table 4) were calculated using the coats-redfern and MKN equations ${ }^{14}$ by graphical as well as least square method (Figure 2 and 3). On the basis of energy of activation values, we found that the complexes show similar type of the decomposition reactions ${ }^{15}$. The energy of activation $\left(E_{a}\right)$ for the decomposition of lattice water was found to be much lower than that for coordinated water and values are closer to the activation energy values for the dehydration reactions ${ }^{16}$. The energy of activation values for the second stage of decomposition of the complexes was found to be lower than those for the third stage decomposition, which indicates an increased rate at this state and might be due to the catalytic effect of the metal complex in the oxidation for the ligands and other decomposition products ${ }^{17}$. The rate of third stage decomposition of the complexes was found to be much higher than the previous two stages due to the higher in energy of activation. The negative entropy of activation values for all degradation stages show that the complexes are more ordered in the activated state through the chemisorption of oxygen and other decomposition products ${ }^{15}$. The negative entropy of activation values are compensated by the values of the energies of activation. The entropy of activation value increases from first step to third step indicates that the rate of decomposition decreases in stepwise reactions ${ }^{18}$. 
Table 3. Thermogravimetric characteristics of lanthanide(III) nitrate complexes

\begin{tabular}{|c|c|c|c|c|c|c|c|c|c|}
\hline \multirow[t]{2}{*}{ Complex } & \multirow[t]{2}{*}{ Process } & \multirow{2}{*}{$\begin{array}{c}\text { Decomposition } \\
\text { temp. range, } \\
\text { K }\end{array}$} & \multirow{2}{*}{$\begin{array}{l}\text { Peak } \\
\text { temp. } \\
\text { K }\end{array}$} & \multirow{2}{*}{$\begin{array}{l}\text { Decomposition } \\
\text { product }\end{array}$} & \multicolumn{2}{|c|}{$\begin{array}{c}\text { Weight loss, } \\
\%\end{array}$} & \multirow{2}{*}{$\begin{array}{l}\text { No. of } \\
\text { moles }\end{array}$} & \multirow{2}{*}{$\frac{\text { Residue }}{\text { Obs(Cald) }}$} & \multirow[t]{2}{*}{$\begin{array}{l}\text { Residue } \\
\text { nature }\end{array}$} \\
\hline & & & & & Obs. & Calcd. & & & \\
\hline \multirow[t]{3}{*}[\mathrm{La}(\mathrm{L}^{1}\mathrm{H})_{2}\mathrm{NO}_{3}]{$\mathrm{H}_{2} \mathrm{O}$} & Dehydration & $348-408$ & 378 & $\mathrm{H}_{2} \mathrm{O}$ & 2.05 & 2.07 & 1 & & \\
\hline & $\begin{array}{c}\text { Decomposition of } \\
\text { coordination sphere } \\
\left(\mathrm{L}^{1} \mathrm{H} \text { and } \mathrm{NO}_{3}\right)\end{array}$ & $408-678$ & 508 & $\begin{array}{l}\mathrm{L}^{1} \mathrm{H} \text { and } \\
\mathrm{NO}_{3}\end{array}$ & 43.01 & 42.57 & $\begin{array}{l}1 \\
1\end{array}$ & & \\
\hline & $\begin{array}{l}\text { Decomposition of } \\
\text { coordination sphere }\left(\mathrm{L}^{1} \mathrm{H}\right)\end{array}$ & $678-958$ & 853 & $\mathrm{~L}^{1} \mathrm{H}$ & 35.94 & 35.42 & 1 & $\begin{array}{c}37.82 \\
(37.56)\end{array}$ & $\mathrm{La}_{2} \mathrm{O}_{3}$ \\
\hline \multirow[t]{3}{*}[\mathrm{Nd}(\mathrm{L}^{1}\mathrm{H})_{2}\mathrm{NO}_{3}]{$\mathrm{H}_{2} \mathrm{O}$} & Dehydration & $358-398$ & 371 & $\mathrm{H}_{2} \mathrm{O}$ & 2.03 & 2.03 & 1 & & \\
\hline & $\begin{array}{l}\text { Decomposition of } \\
\text { coordination sphere } \\
\left(\mathrm{L}^{1} \mathrm{H} \text { and } \mathrm{NO}_{3}\right)\end{array}$ & $398-718$ & 503 & $\begin{array}{c}\mathrm{L}^{1} \mathrm{H} \text { and } \\
\mathrm{NO}_{3}\end{array}$ & 42.60 & 42.60 & $\begin{array}{l}1 \\
1\end{array}$ & & \\
\hline & $\begin{array}{c}\text { Decomposition of } \\
\text { coordination sphere }\left(\mathrm{L}^{1} \mathrm{H}\right)\end{array}$ & $718-978$ & 805 & $\mathrm{~L}^{1} \mathrm{H}$ & 34.78 & 34.78 & 1 & $\begin{array}{c}38.84 \\
(38.57)\end{array}$ & $\mathrm{Nd}_{2} \mathrm{O}_{3}$ \\
\hline \multirow[t]{3}{*}[\mathrm{Gd}(\mathrm{L}^{3}\mathrm{H})_{2}\mathrm{NO}_{3}]{$\mathrm{H}_{2} \mathrm{O}$} & Dehydration & $328-378$ & 358 & $\mathrm{H}_{2} \mathrm{O}$ & 1.87 & 1.87 & 1 & & \\
\hline & $\begin{array}{l}\text { Decomposition of } \\
\text { coordination sphere } \\
\left(\mathrm{L}^{3} \mathrm{H} \text { and } \mathrm{NO}_{3}\right)\end{array}$ & $378-708$ & 521 & $\begin{array}{c}\mathrm{L}^{3} \mathrm{H} \text { and } \\
\mathrm{NO}_{3}\end{array}$ & 41.96 & 41.96 & $\begin{array}{l}1 \\
1\end{array}$ & & \\
\hline & $\begin{array}{l}\text { Decomposition of } \\
\text { coordination sphere }\left(\mathrm{L}^{3} \mathrm{H}\right)\end{array}$ & $708-998$ & 818 & $\mathrm{~L}^{3} \mathrm{H}$ & 35.47 & 35.47 & 1 & $\begin{array}{c}38.50 \\
(38.22)\end{array}$ & $\mathrm{Gd}_{2} \mathrm{O}_{3}$ \\
\hline
\end{tabular}


Table 4. Kinetic parameters of complexes using Coats-Redfern (MKN) equation

\begin{tabular}{|c|c|c|c|c|c|}
\hline Complex & $\begin{array}{l}\text { Decomposition } \\
\text { stage }\end{array}$ & 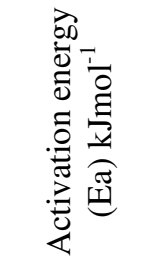 & 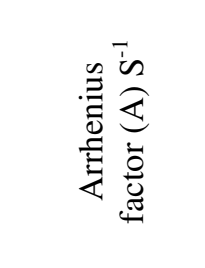 & 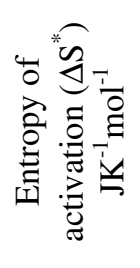 & 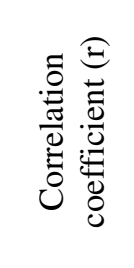 \\
\hline \multirow[t]{6}{*}[\mathrm{La}(\mathrm{L}^{1}\mathrm{H})_{2}\mathrm{NO}_{3}]{$\mathrm{H}_{2} \mathrm{O}\left(\mathrm{C}_{1}\right)$} & I & 13.6075 & 7.1876 & -231 & 0.9982 \\
\hline & & (13.5737) & (4.2784) & $(-235)$ & (0.9986) \\
\hline & II & 39.5023 & $21.388 \times 10^{3}$ & -167 & 0.9970 \\
\hline & & (39.1788) & $\left(10.974 \times 10^{3}\right)$ & $(-172)$ & (0.9972) \\
\hline & III & 48.7880 & $31.012 \times 10^{4}$ & -104 & 0.9976 \\
\hline & & $(48.2668)$ & $\left(24.226 \times 10^{4}\right)$ & $(-107)$ & (0.9980) \\
\hline \multirow{6}{*}[\mathrm{Nd}(\mathrm{L}^{1}\mathrm{H})_{2}\mathrm{NO}_{3}]{$\mathrm{H}_{2} \mathrm{O}\left(\mathrm{C}_{7}\right)$} & I & 15.5843 & 33.2416 & -222 & 0.9997 \\
\hline & & $(15.2123)$ & $(21.0524)$ & $(-218)$ & (0.9997) \\
\hline & II & 26.8450 & $6.93 \times 10^{2}$ & -195 & 0.9984 \\
\hline & & (26.7779) & $\left(4.0395 \times 10^{2}\right)$ & $(-200)$ & (0.9988) \\
\hline & III & 52.6692 & $55.287 \times 10^{4}$ & -101 & 0.9990 \\
\hline & & $(52.5357)$ & $\left(52.078 \times 10^{4}\right)$ & $(-104)$ & $(0.9981)$ \\
\hline \multirow[t]{6}{*}[\mathrm{Gd}(\mathrm{L}^{5}\mathrm{H})_{2}\mathrm{NO}_{3}]{$\mathrm{H}_{2} \mathrm{O}\left(\mathrm{C}_{15}\right)$} & I & 17.2690 & 47.5916 & -215 & 0.9992 \\
\hline & & (17.4269) & (29.7628) & $(-129)$ & (0.9994) \\
\hline & II & 28.5178 & $1.721 \times 10^{3}$ & -188 & 0.9986 \\
\hline & & (28.4706) & $\left(1.006 \times 10^{3}\right)$ & $(-219)$ & (0.9976) \\
\hline & III & 42.6876 & $5.042 \times 10^{4}$ & -112 & 0.9980 \\
\hline & & $(42.4025)$ & $\left(3.4613 \times 10^{4}\right)$ & $(-113)$ & $(0.9988)$ \\
\hline
\end{tabular}
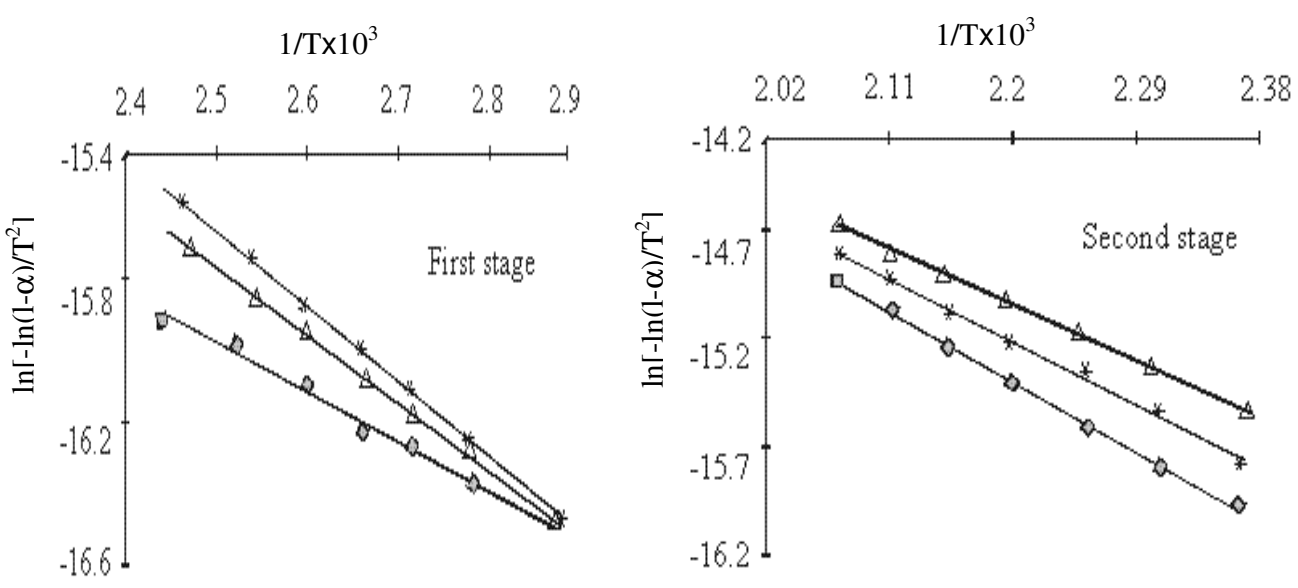


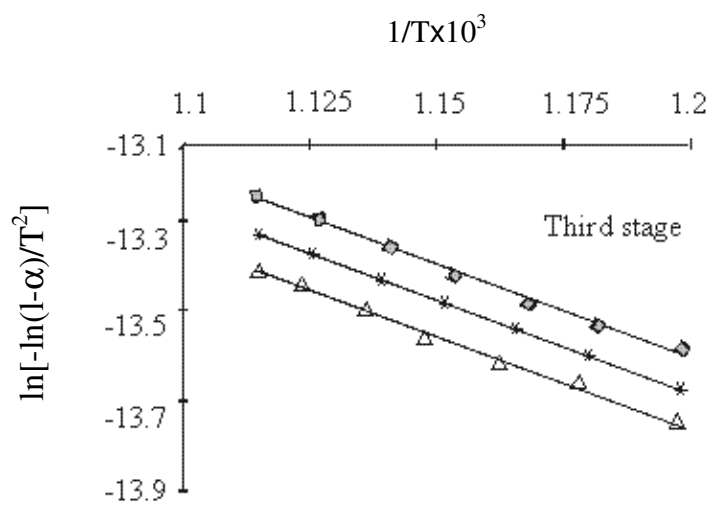

Figure 2. Coats-Redfern plots for the three decomposition steps of the complexes $\diamond\left[\mathrm{La}\left(\mathrm{L}^{1} \mathrm{H}\right)_{2} \mathrm{NO}_{3}\right] \mathrm{H}_{2} \mathrm{O} ; \Delta\left[\mathrm{Nd}\left(\mathrm{L}^{1} \mathrm{H}\right)_{2} \mathrm{NO}_{3}\right] \mathrm{H}_{2} \mathrm{O}$ and $\left.{ }^{*}\left[\mathrm{Gd}\left(\mathrm{L}^{5} \mathrm{H}\right)_{2} \mathrm{NO}_{3}\right] \mathrm{H}_{2} \mathrm{O}\right]$
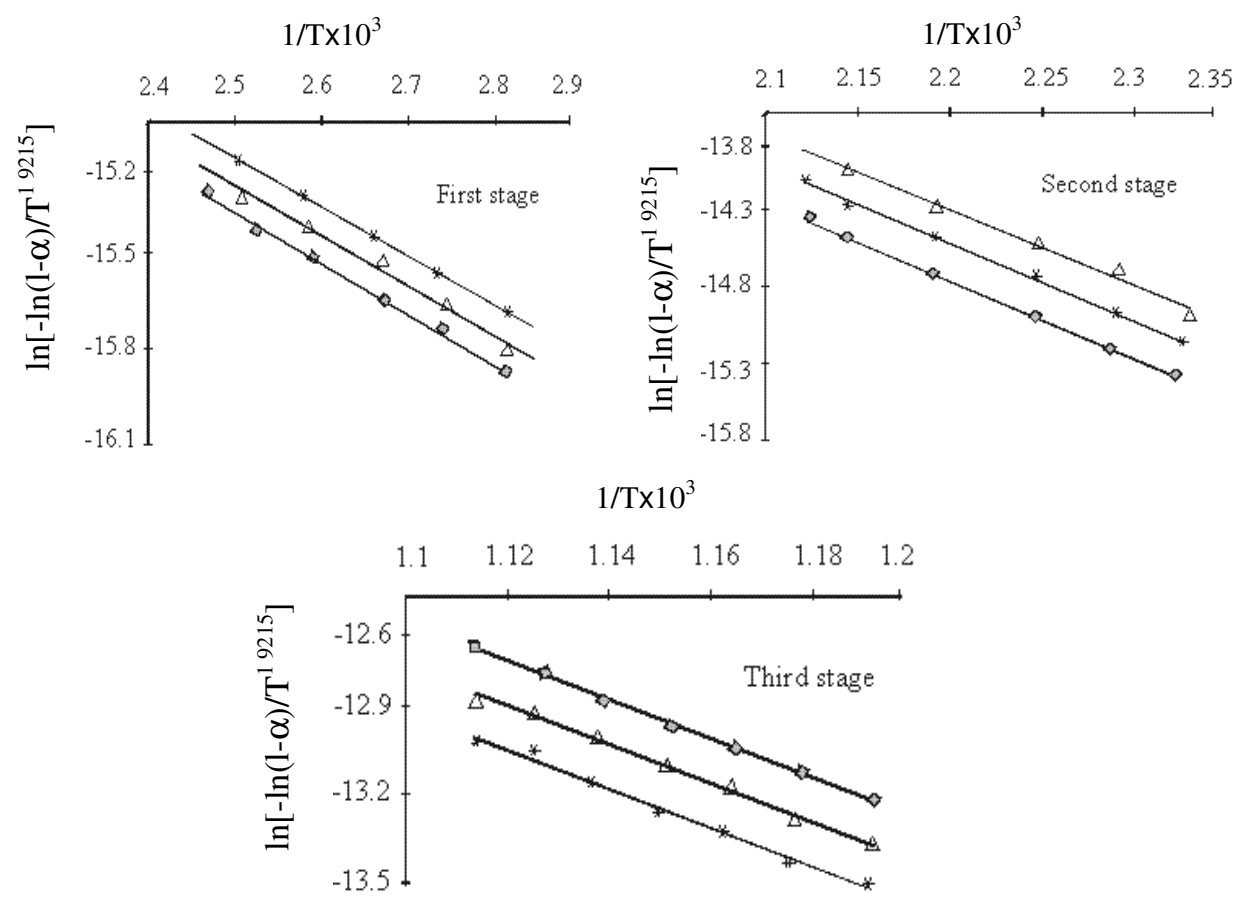

Figure 3. MKN plots for the three decomposition steps of the complexes $\diamond\left[\mathrm{La}\left(\mathrm{L}^{1} \mathrm{H}\right)_{2} \mathrm{NO}_{3}\right] \mathrm{H}_{2} \mathrm{O} ; \Delta\left[\mathrm{Nd}\left(\mathrm{L}^{1} \mathrm{H}\right)_{2} \mathrm{NO}_{3}\right] \mathrm{H}_{2} \mathrm{O}$ and $\left.{ }^{*}\left[\mathrm{Gd}\left(\mathrm{L}^{5} \mathrm{H}\right)_{2} \mathrm{NO}_{3}\right] \mathrm{H}_{2} \mathrm{O}\right]$

\section{Antimicrobial activity}

The antimicrobial activity was carried out using cup plate method ${ }^{19}$ with two different bacteria Escherichia coli and Bacillus cirroflagellasus and two fungal species Aspergillus niger and Candida albicans on base layer medium. The antimicrobial activity results of the screened compounds are given in the Table 5. The activity of the hydrazones have not profoundly increased on complexation with lanthanide(III) ions. Sm(III) and Gd(III) complexes are moderately active against Bacillus cirroflagellosus, $\operatorname{Pr}(\mathrm{III})$ and $\mathrm{Nd}(\mathrm{III})$ complexes 
are moderately active against Excherichia coli. Overall the ligands and their lanthanide(III) complexes are less active as compared to the standards Cotrimoxazole and Flucanozole used in the present study.

Table 5. Antimicrobial activity of ligands and their lanthanides(III) nitrate complexes

\begin{tabular}{|c|c|c|c|c|}
\hline \multirow{2}{*}{ Compound } & \multicolumn{2}{|c|}{$\begin{array}{c}\text { Antibacterial activity of zone } \\
\text { of inhibition, mm }\end{array}$} & \multicolumn{2}{|c|}{$\begin{array}{l}\text { Antifungal activity of zone } \\
\text { of inhibition, mm }\end{array}$} \\
\hline & $\begin{array}{l}\text { B. cirrof } \\
\text { lagellasus }\end{array}$ & E. Coli & A. niger & C. albicans \\
\hline $\mathrm{C}_{16} \mathrm{H}_{14} \mathrm{~N}_{4} \mathrm{O}_{2} \mathrm{~S}\left(\mathrm{~L}^{1} \mathrm{H}_{2}\right)$ & 14 & 13 & 15 & 14 \\
\hline $\mathrm{C}_{17} \mathrm{H}_{16} \mathrm{~N}_{4} \mathrm{O}_{2} \mathrm{~S}\left(\mathrm{~L}^{2} \mathrm{H}_{2}\right)$ & 13 & 14 & 14 & 13 \\
\hline $\mathrm{C}_{17} \mathrm{H}_{16} \mathrm{~N}_{4} \mathrm{O}_{3} \mathrm{~S}\left(\mathrm{~L}^{3} \mathrm{H}_{2}\right)$ & 14 & 12 & 13 & 12 \\
\hline$\left[\mathrm{La}\left(\mathrm{L}^{1} \mathrm{H}\right)_{2} \mathrm{NO}_{3}\right] \mathrm{H}_{2} \mathrm{O}$ & 15 & 14 & 16 & 15 \\
\hline$\left[\mathrm{La}\left(\mathrm{L}^{2} \mathrm{H}\right)_{2} \mathrm{NO}_{3}\right] \mathrm{H}_{2} \mathrm{O}$ & 13 & 15 & 14 & 14 \\
\hline$\left[\mathrm{La}\left(\mathrm{L}^{3} \mathrm{H}\right)_{2} \mathrm{NO}_{3}\right] \mathrm{H}_{2} \mathrm{O}$ & 15 & 13 & 14 & 14 \\
\hline$\left[\operatorname{Pr}\left(\mathrm{L}^{1} \mathrm{H}\right)_{2} \mathrm{NO}_{3}\right] \mathrm{H}_{2} \mathrm{O}$ & 14 & 16 & 15 & 14 \\
\hline$\left[\mathrm{Pr}\left(\mathrm{L}^{2} \mathrm{H}\right)_{2} \mathrm{NO}_{3}\right] \mathrm{H}_{2} \mathrm{O}$ & 14 & 17 & 15 & 14 \\
\hline$\left[\mathrm{Pr}\left(\mathrm{L}^{3} \mathrm{H}\right)_{2} \mathrm{NO}_{3}\right] \mathrm{H}_{2} \mathrm{O}$ & 15 & 16 & 14 & 15 \\
\hline$\left[\mathrm{Nd}\left(\mathrm{L}^{1} \mathrm{H}\right)_{2} \mathrm{NO}_{3}\right] \mathrm{H}_{2} \mathrm{O}$ & 15 & 17 & 16 & 15 \\
\hline$\left[\mathrm{Nd}\left(\mathrm{L}^{2} \mathrm{H}\right)_{2} \mathrm{NO}_{3}\right] \mathrm{H}_{2} \mathrm{O}$ & 14 & 18 & 14 & 14 \\
\hline$\left[\mathrm{Nd}\left(\mathrm{L}^{3} \mathrm{H}\right)_{2} \mathrm{NO}_{3}\right] \mathrm{H}_{2} \mathrm{O}$ & 14 & 16 & 13 & 13 \\
\hline$\left[\mathrm{Sm}\left(\mathrm{L}^{1} \mathrm{H}\right)_{2} \mathrm{NO}_{3}\right] \mathrm{H}_{2} \mathrm{O}$ & 18 & 15 & 16 & 14 \\
\hline$\left[\mathrm{Sm}\left(\mathrm{L}^{2} \mathrm{H}\right)_{2} \mathrm{NO}_{3}\right] \mathrm{H}_{2} \mathrm{O}$ & 17 & 15 & 14 & 14 \\
\hline$\left[\mathrm{Sm}\left(\mathrm{L}^{3} \mathrm{H}\right)_{2} \mathrm{NO}_{3}\right] \mathrm{H}_{2} \mathrm{O}$ & 18 & 13 & 14 & 13 \\
\hline$\left[\mathrm{Gd}\left(\mathrm{L}^{1} \mathrm{H}\right)_{2} \mathrm{NO}_{3}\right] \mathrm{H}_{2} \mathrm{O}$ & 17 & 14 & 15 & 15 \\
\hline$\left[\mathrm{Gd}\left(\mathrm{L}^{2} \mathrm{H}\right)_{2} \mathrm{NO}_{3}\right] \mathrm{H}_{2} \mathrm{O}$ & 17 & 15 & 15 & 13 \\
\hline$\left[\mathrm{Gd}\left(\mathrm{L}^{3} \mathrm{H}\right)_{2} \mathrm{NO}_{3}\right] \mathrm{H}_{2} \mathrm{O}$ & 18 & 13 & 14 & 14 \\
\hline Contrimoxazole & 24 & 21 & - & - \\
\hline Flucanozole & - & - & 24 & 23 \\
\hline
\end{tabular}

\section{Conclusion}

Based on the elemental analysis and various physicochemical studies the empirical formula $\left[\mathrm{Ln}(\mathrm{LH})_{2} \mathrm{NO}_{3}\right] \mathrm{H}_{2} \mathrm{O}$ (Figure 4) have been tentatively proposed for the present complexes involving a monobasic terdentate functional ligand in keto form and an eight coordinate metal ion.

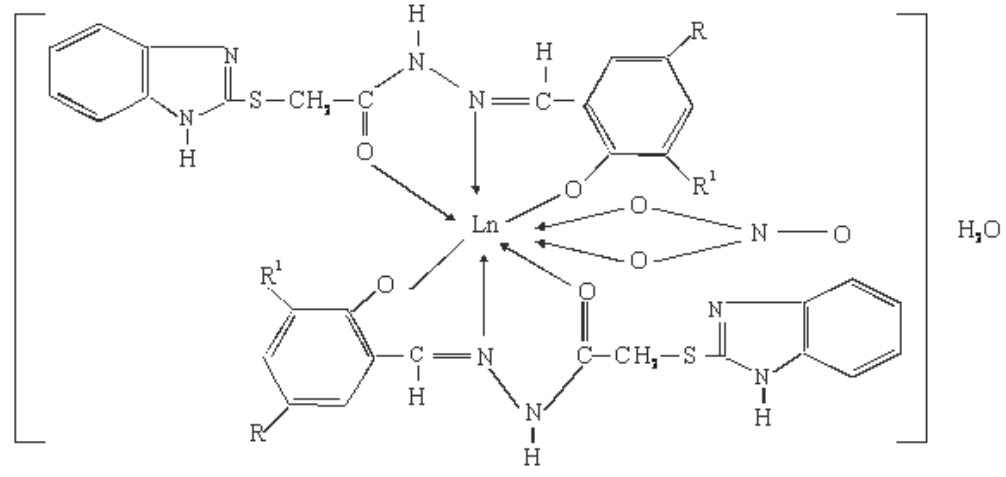

$(\mathrm{Ln}=\mathrm{La}, \mathrm{Pr}, \mathrm{Nd}, \mathrm{Sm}$ and $\mathrm{Gd})$

Figure 4. Structure of lanthanide(III) nitrate complex 


\section{References}

1. Alexander V, Chem Rev., 1995, 2, 95.

2. Haran A, Gairin J and Commenges G, Inorg Chim Acta, 1980, 46, 63-67

3. Naik V M and Mallur N B, Indian J Chem., 2002, 41A, 780-784.

4. $\quad$ Naik V M, Patil S K, Tallur S B and Mallur N B, J Indian Chem Soc., 2008, 85, 22-25.

5. Naik V M, Sambrani M I and Mallur N B, Indian J Chem., 2008, 47(12)A, 1793-1797.

6. $\quad$ Singh S P, Parmar S S and Pandey B R, J Heterocycl Chem., 1977, 14, 1093.

7. Geary W G, Coord Chem Rev, 1971, 7, 81.

8. Sinha S P, Complexes of Rare Earths, Vol. IV, Pergaman Press, New York, 1966.

9. Leoric V M, Vielica L J, Jovanovic L S and Choundak S, Polyhedron, 1986, 5, 983.

10. Dey K, Bhatacharya P K, Bandyopadhyay D, Chakraborty K and Mallik A K, Indian J Chem., 1995, 34A, 529.

11. Ankolekar V N and Mahale V B, Synth React Inorg Met Org Chem., 2000, 30(7), 1193.

12. Alaudeen M and Prabhakaran C P, Indian J Chem., 1996, 35A, 517.

13. Curtis N F and Curtis Y M, Inorg Chem., 1965, 4, 804.

14. Madhusudanan P M, Krishanan K and Ninan K N, Thermochem Acta, 1986, 97, 189-201.

15. Madhusudanan P M, Mohammud Yusuff K K and Nair C G R, J Therm Anal., 1975, 8, 31-43.

16. Wendlandt W W, Thermal methods of Analysis, $2^{\text {nd }}$. Edition, John Wiley and Sons, New York, 1974.

17. Maravalli P B and Goudar T R, Thermochim Acta, 1999, 325, 35.

18. Seregar V C, Hiremath C V and Nandibewoor S T, Trans Met Chem., 2006, 31, 541.

19. Seeley H W and Van Demark P J, Microbes in Action; A Laboratory Manual of Microbiology, $2^{\text {nd }}$ Edition, India; Taroporevala D.B. Sons and Co. Pvt. Ltd., 1975. 


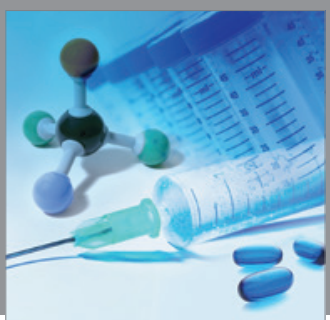

International Journal of

Medicinal Chemistry

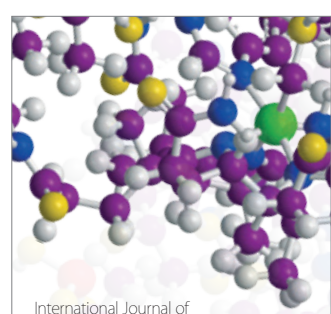

Carbohydrate Chemistry

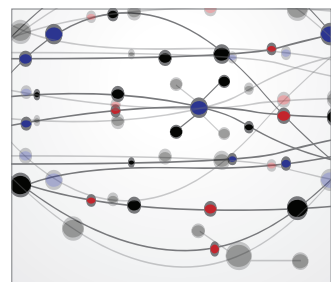

The Scientific World Journal
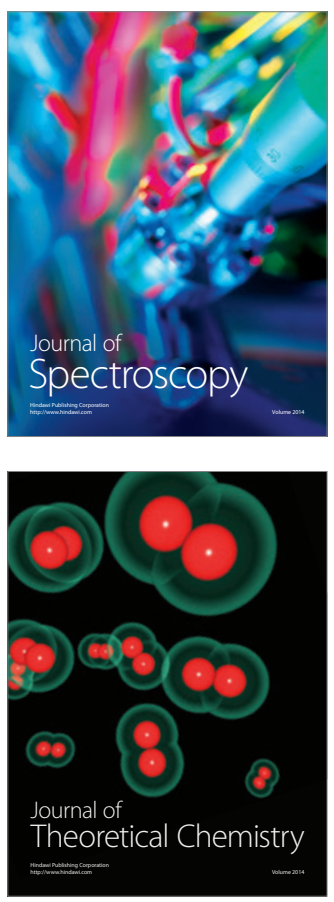
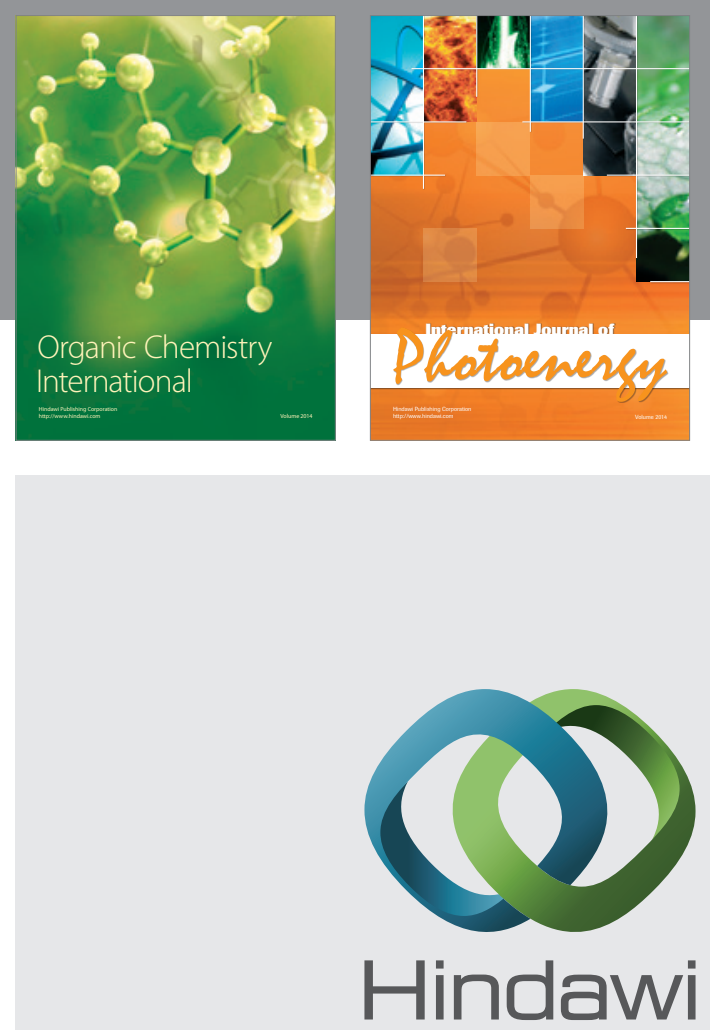

Submit your manuscripts at

http://www.hindawi.com
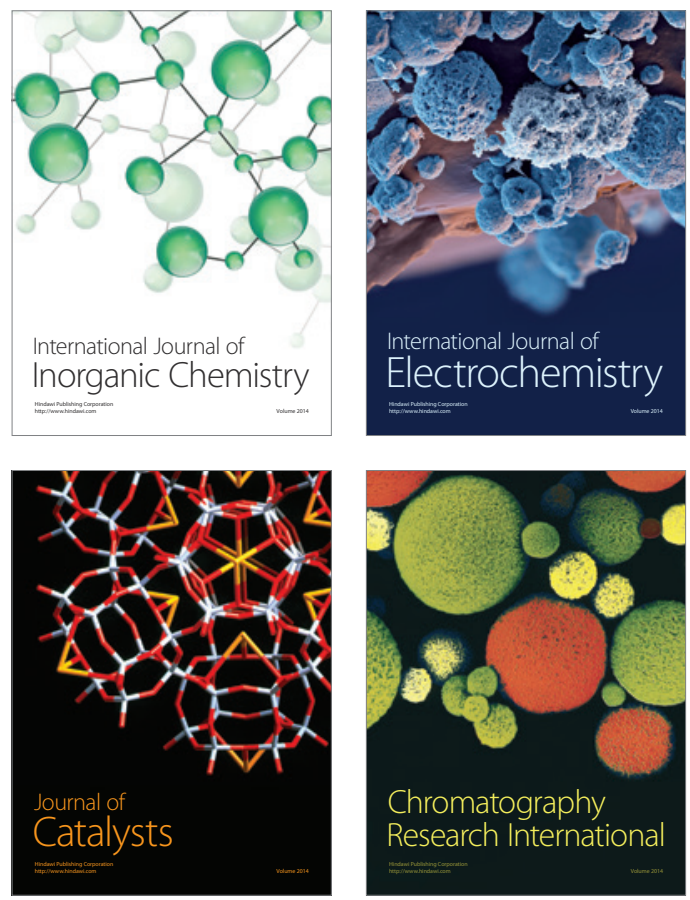
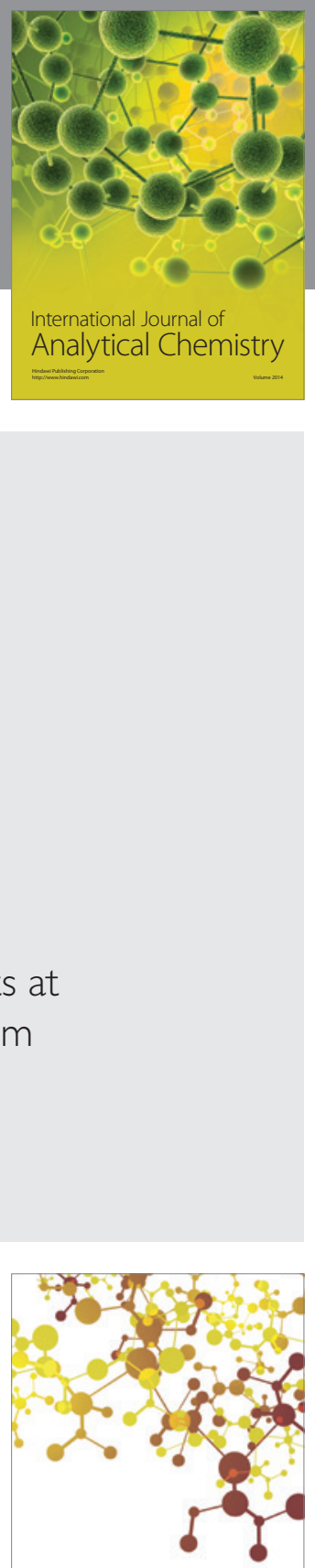

Journal of

Applied Chemistry
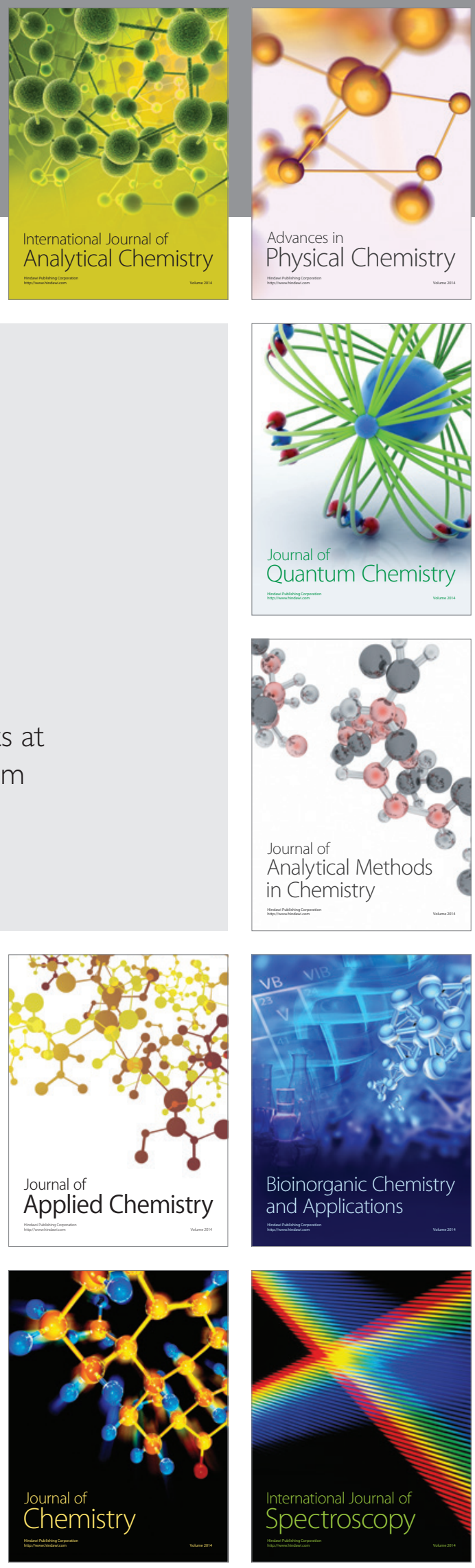